\title{
Exploring the Relationship between Types of Family Involvement and \\ Collaborative Innovation in Design-Intensive Firms: Insights from Two \\ Leading Players in the Furniture Industry
}

\begin{abstract}
Innovation in family firms has attracted considerable interest from scholars and practitioners in recent years. However, further theoretical and empirical research is needed to shed light on the intricate relationship between family involvement and innovation. This article studies the effect of different types of family involvement on the management of collaborative innovation. Based on empirical evidence from two leading Italian design-intensive firms in the furniture industry (B\&B Italia and Cassina), this study illuminates how family involvement in control and management influences the way designintensive firms collaborate with external designers to innovate their products. We use two indicators, design renewal and design identity, to capture differences in the collaboration approaches through which design-intensive family firms involve external designers in the innovation process. Focusing on a thus far neglected aspect, namely, how family involvement shapes collaborative innovation, our findings contribute to understanding how collaborative innovation is managed in family firms. This article also provides family firm owners and managers with valuable insights on the forces that influence collaborative innovation processes in design-intensive firms.
\end{abstract}

Keywords: Family firms, design, design-intensive firms, furniture industry, innovation, open innovation

\section{Introduction}

Innovation and family business scholars have increasingly paid attention to studying the antecedents, consequences, and anatomy of innovation in family firms (Duran et al. 2016; De Massis et al. 2016; Chrisman et al. 2015a; De Massis, Frattini, and Lichtenthaler 2013). Family firms are defined as businesses governed and managed with the intention of pursuing the vision of a dominant coalition controlled by members of the founding family and potentially sustainable across generations (Chua, Chrisman, and Sharma 1999). Theoretical and empirical research clearly shows that family firms have highly idiosyncratic behaviours, which 
distinguish them from their non-family counterparts, in areas such as internationalisation (Zahra 2003), entrepreneurship (Naldi et al. 2007), and finance (Romano Tanewski, and Smyrnios 2001). This is attributed to the involvement of one or more families in firm ownership and control, entailing distinctive incentives, authority structures, and accountability norms, with strong effects on how decisions are taken and implemented (Gedajlovic, Lubatkin, and Schulze 2004). Research shows that these idiosyncratic characteristics also affect how innovation takes place in family firms, as well as its antecedents and outcomes. For instance, recent research suggests that family firms are characterised by a paradoxical condition whereby they are less willing to pursue innovation projects compared to their non-family counterparts, even if they are more capable of successfully completing these projects (Chrisman et al. 2015a). This notwithstanding, there is a need for further rigorous theoretical and empirical research to understand innovation in family firms in its entire complexity (Duran et al. 2016; De Massis, Di Minin, and Frattini 2015a). Pushing the frontier of academic research in this direction could lead to significant theoretical and managerial implications. Indeed, most knowledge in the innovation management and policy fields has derived from studying private, publicly traded firms characterised by strong ownership fragmentation and a clear separation between ownership and management (De Massis et al. 2013). Moreover, this research stream largely overlooks the impact of the characteristics of firms with family involvement on the innovation processes and outcomes (De Massis et al. 2016; Filser et al. 2017). Further research on innovation in family firms is also needed given that these firms are the most ubiquitous form of business organisation globally and exert considerable influence on the economy and society in most countries (La Porta et al. 1999; Villalonga and Amit 2009). For instance, family firms represent approximately $85 \%$ of the entire population of firms in OECD nations, and $35 \%$ of Fortune 500 and S\&P 500 firms (Craig et al. 2014). Developing a more fine-grained understanding of how innovation in family firms can be managed or fostered through 
appropriately designed policies would positively impact the competitiveness of large sectors of the economy of industrialised as well as developing countries.

This article contributes to the growing research on innovation in family firms by studying the effect of different types of family involvement in a business organisation on collaborative innovation, defined as the relationship between the firm and external parties aimed at exchanging and sharing resources to achieve innovation (Feranita, Kotlar, and De Massis 2017). More specifically, we aim to answer the following research question: How and why does the type of family involvement influence collaborative innovation in design-intensive firms? We address this research question through the case studies of two Italian design-intensive firms operating in the furniture industry (B\&B Italia and Cassina). The particularity of these two firms is that family involvement evolved and substantially changed over time, and collaborative innovation is at the core of their competitive strategy, providing an extraordinary opportunity to address our research question. A longitudinal study of how these firms have changed the way they develop their products by collaborating with external designers sheds light on the intricate relationship between family involvement and collaborative innovation in design-intensive family firms. The decision to focus on design-intensive firms is due to the fact that in these organisations, the role and involvement of the founding and controlling family in product innovation and their interest in preserving the family name and identity across generations of new products are of paramount importance (Dalpiaz, Rindova, and Ravasi 2016).

With design-intensive firms we indicate those companies that heavily rely on the creativity and innovative contributions that designers bring to the development of their new products (Dell'Era and Verganti 2010, 2011). The importance of design-intensive firms for developed economies is widely acknowledged. For instance, a study by the (former) Office for Harmonization in the Internal Market/European Patent Office of the European Commission 
estimated that these firms generated $12.2 \%$ of employment and $12.8 \%$ of GDP in the European Union in $2013^{1}$.

Our study contributes to current knowledge in several ways. First, we focus on how innovation takes place and is managed in family firms, which is a rather neglected aspect in research where the focus is more on the inputs and outputs of innovation processes (Calabrò et al. 2018; De Massis et al. 2013; Röd 2016). In this respect, the longitudinal perspective we adopt seems particularly useful to illuminate the intricate relationship between different types of family involvement and the decisions family firms take when collaborating with external designers in innovation processes. Prior family business studies have mostly researched the effect on firm behaviour of variations in the degree of family involvement, neglecting how variations in the type of family involvement may also shape such behaviour (Chrisman et al. 2015b). Second, this article responds to recent calls to consider the heterogeneity of family firms in studying their idiosyncratic behaviours, among which innovation (De Massis et al. 2015a; Chua et al. 2012). Family firms are not a homogeneous entity, and understanding their differences can lead to a better interpretation of their behaviours. Third, this study looks into the complex issue of innovation in family firms by focusing on design-intensive companies, to date overlooked by research on family business innovation. This is surprising considering that in design-intensive firms, the owning and controlling family (or families) is (are) typically more directly involved in innovation compared to other firms (Dalpiaz, Tracey, and Philips 2014).

The article is structured as follows. Section 2 provides the theoretical background and develops the underlying conceptual framework. Section 3 illustrates the methodology used in the empirical analysis. Section 4 presents the results of the two case studies. Section 5 contains the discussion, and Section 6 concludes and outlines avenues for future research.

\footnotetext{
1 'Intellectual property rights intensive industries: contribution to economic performance and employment in the European Union - Industry-Level Analysis Report 2013' report of the European Patent Office and the Office for Harmonization in the Internal Market (http://ec.europa.eu/internal_market/intellectual-property/docs/joint-reportepo-ohim-final-version_en.pdf).
} 


\section{Theoretical Background}

This section briefly reviews two research streams that provide the theoretical underpinning of our study, i.e., innovation in design-intensive firms and innovation in family firms. In both cases, particular attention is paid to the collaborative innovation processes taking place in design-intensive and family firms.

\subsection{Collaborative Innovation in Design-Intensive Firms}

Design is increasingly becoming a strategic source of competitive advantage, and scholars have progressively focused on identifying the managerial practices that allow companies to capture value from collaborations with designers (Capaldo 2007; Dell'Era, Marchesi, and Verganti 2008a, 2017; Dell'Era and Verganti 2009b 2010; Ravasi, Rindova, and Stigliani 2018). The emergence of new paradigms, such as human-centred design (Buchanan 2001), participatory design (Sanders and Stappers 2008), and especially design thinking (Brown 2008; Martin 2009), highlight the critical role that design can play in the field of innovation today.

As design becomes an increasingly important source of knowledge for innovation, collaborative innovation processes involving designers have grown in relevance (Cillo and Verona 2008; Dell'Era and Verganti 2010; Dell'Era, Magistretti, and Verganti 2018). Many recent studies underline the crucial role that designers play in collaborative innovation processes, especially in design-intensive industries where aesthetics and experiential product features significantly influence consumer choices (Lloyd and Snelders 2003; Verganti 2003 2006; Bertola and Texeira 2003; Durgee 2006; Swan and Luchs 2011). The growing importance of designers is also clear when considering that some are deemed real 'superstars': Jonathan Ive for Apple, Jacob Jensen for Bang \& Olufsen, Philippe Starck for several furniture companies, but also for Nike. According to D'Ippolito (2014), designers can contribute to 
collaborative innovation processes in different ways, from creating artefacts to solving problems, from making sense of things to supporting strategy definition. Perks, Cooper, and Jones (2005) introduce a taxonomy of the different contributions that designers can provide in collaborative innovation processes: functional specialists (designers focus purely on design and are perceived by the business as a resource), part of multifunctional teams (designers emerge as key players of the team), process leaders (designers drive and support activities throughout the entire development process). According to Verganti (2003 2006, 2009), involving designers in the innovation process allows companies to access and interpret knowledge on customer needs and values. By observing and interpreting consumer behaviours and emerging lifestyles in society, designers can propose new meanings and languages to feed that innovation process (Verganti 2009).

Research on innovation in design-intensive firms highlights the need to adequately manage the trade-off between design renewal, defined as the ability to continuously refresh the portfolio of designers with whom the firm collaborates for innovation purposes (Dell'Era and Verganti 2007; Dell'Era et al. 2008b), and design identity, which refers to their attempt to strengthen the relationship with the existing portfolio of designers and work with them over time to increase product recognition in the market. Dell'Era and Verganti (2010) show that collaborative innovation processes managed by leading innovators in design-intensive industries are based on a broad range of partners to guarantee the continuous renewal of the product portfolio. The knowledge diversity resulting from collaborating with diverse and multiple external knowledge sources (and particularly designers) can positively affect the ability to innovate (Gulati 1998; McEvily and Zaheer 1999; Rodan and Galunic 2004). Moreover, continuously renewing the portfolio of designers mitigates the problems associated with periods of low creativity that some designers may go through, refreshing the approaches adopted in the innovation process (Dell'Era and Verganti 2010). Although collaborations with new designers can bring significant 
advantages, the potential drawbacks of this approach also need to be carefully considered. Especially in industries where product identity is crucial, firms have to manage the delicate trade-off between being too innovative and maintaining their identity (Micheli and Gemser 2016). Companies can adopt several means to increase the recognition of their brand and products in the market. Design is one of the main vehicles adopted to convey and strengthen product identity (Schmitt and Simonson 1997; Stompff 2003; Borja de Mozota 2004). Recent research shows that the integration of design resources can positively influence product identity (Beverland 2005; Durgee 2006; Karjalainen and Snelders 2010; Ravasi and Stigliani 2012). Product identity is a fundamental lever to increase recognition and brand awareness, and differentiate the firm's offering from that of competitors. In this regard, designers can significantly influence the identity by developing product signs that convey consistent messages to customers (McCormack and Cagan 2004). As a consequence, leading innovators in design-intensive industries tend to maintain long-lasting relationships with a few historical designers who can preserve product identity (Dell'Era and Verganti 2007, 2010). Through a longitudinal study of three leading firms operating in design-intensive industries, Capaldo (2007) shows that the ability to integrate a large periphery of heterogeneous weak ties with designers, together with a core of strong ties, can positively influence innovation performance. More in detail, Capaldo (2007) operationalises the strength of the inter-organisational relationship with designers along three variables: (1) the overall duration of the relationship; (2) the frequency of the collaboration; and (3) the intensity of the collaboration. In other words, long-lasting, frequent, and intense collaborations between firms and designers imply strong ties that significantly influence product identity.

Although it is widely acknowledged that family firms have a strong presence in designintensive industries, and that the controlling family (families) is (are) heavily involved in innovation decisions and activities (Dalpiaz et al. 2014), existing research fails to unearth how 
and why the distinctive and varied characteristics of family involvement in design-intensive family firms may influence innovation processes, and particularly how collaborations with designers are managed. This paper is a first attempt to shed light on this important issue.

\subsection{Collaborative Innovation in Family Firms}

Research on innovation in family firms has expanded rapidly in recent years (De Massis et al. 2013; Duran et al. 2016). Scholars have started to look at the collaborative aspects of the innovation process in family firms, particularly how collaborations with external organisations allow accessing critical resources, including capital, information, knowledge, and technology (for a comprehensive review, see Feranita et al. 2017) or help family firms 'do more with less' (e.g., De Massis et al. 2018). For example, Classen et al. (2012) examine how family involvement influences the depth and breadth of search for external resources leading to innovation in family led small- and medium-sized enterprises (SMEs). Block and Spiegel (2013) study the role of family firms in promoting knowledge spillovers within a region, where the propensity of family firms to collaborate with other firms potentially contributes to regional innovation outputs by boosting successful patent applications. Lambrechts et al. (2017) conduct an exploratory investigation of how four private Belgian family SMEs in low- and mediumtechnology industries can successfully engage in open innovation and what factors account for their success. Casprini et al. (2017) highlight through a single case study of an Italian family firm how it overcame knowledge management barriers in executing an open innovation strategy. Other scholars examine the behavioural barriers that prevent family firms from acquiring external technology (Konig, Kammerlander, and Enders 2013; Kotlar et al. 2013). However, although this body of research is rich in insights, existing literature on collaborative innovation in family firms remains limited, and none of these studies specifically investigates how family involvement in a firm might affect collaborative innovation. 
Moreover, recent research on family firm heterogeneity (e.g., Sharma and Nordqvist 2008; Chua et al. 2012) points to the importance of recognising that different family firms may be characterised by heterogeneous governance structures, and that even the governance structure of the same family firm may change over time (e.g., Gersick 1997). This line of research also recognises the importance of considering such heterogeneity to understand family firm behaviour (e.g., Chrisman et al. 2015b). The degree of family involvement is acknowledged as a first important driver of family firm heterogeneity (e.g., De Massis et al. 2014b). It is reasonable to assume that how much a family is involved in a business organisation influences firm behaviour. However, assuming that a single, linear construct can capture how such involvement is exercised is problematic, since how family involvement translates into firm behaviour is likely to vary in type according to the goals and abilities of those who control the family firm, those who are involved in its management, and the family generation in charge. For instance, powerful non-family owners, such as institutional investors, may constrain the family owners' ability to exercise their control (Howorth, Westhead, and Wright 2004), and the degree of family control can therefore vary across family firms. Generation is another important cause of heterogeneity, given that the incentives and authority structures of family involvement can change as the family firm progresses from one generation to the next (Kellermanns and Eddleston 2006; Kellermanns et al. 2008). First-generation family firms are owned by the founding owner, whereas in second- and subsequent-generation firms, second or later generations of family members become involved (Cruz and Nordqvist 2012; Sonfield and Lussier 2004). This is consistent with prior research distinguishing between lone founder and later-generation family firms (e.g., Miller et al. 2007; Le Breton-Miller and Miller 2008). Finally, different involvement in management is another source of heterogeneity, as different family firms may vary in the extent to which the controlling family is responsible for orchestrating and affecting the decision-making process. For instance, prior empirical research 
shows that differences in family management result in distinct family firm behaviours and performance (e.g., Sciascia and Mazzola 2008).

Drawing on this body of literature, we focus on control, generation, and management as three key aspects characterising the type of family involvement in family firms. As such, we attempt to fill the important gap in current knowledge on how and why the type of family involvement influences collaborative innovation in design-intensive firms.

\subsection{Theoretical Framework}

Starting from the results of the brief literature overview in the two foregoing sections, this article aims to investigate how and why does the type of family involvement influence collaborative innovation in design-intensive firms. Figure 1 shows the theoretical framework underlying this study.

(Figure 1 about here)

As Figure 1 shows, heterogeneity in family involvement can be captured by considering three variables that existing research identifies as important aspects influencing innovation in family firms. These are: (i) family control, which captures the extent to which the controlling family(ies) owns a relevant share in the firm's equity, (ii) family generation, which considers which generation of the family(ies) is in control, namely, first, second, or subsequent generations, and (iii) family management, which measures the extent to which the controlling family(ies) is (are) responsible for managing the decision-making process, and therefore the decisions on collaborations with designers.

Regarding collaborative innovation with designers, Figure 1 shows that the focus of this study is on two aspects that existing research identifies as critical to understanding how these collaborative processes are managed. These aspects are: (i) design renewal, which captures a firm's attitude to starting collaborations with new designers, and (ii) design identity, which 
measures a firm's decision to strengthen collaborations with designers that are already part of its network in the attempt to reinforce product identity. See Appendix A for a detailed operationalisation of these variables.

\section{Methodology}

This section provides details of how we conducted the longitudinal multiple case study analysis.

\subsection{Case Selection}

Given the aims of this article, an exploratory case study methodology seemed the most appropriate (Eisenhardt 1989). Indeed, it is particularly suited to answering 'how' and 'why' questions (Eisenhardt and Graebner 2007; Easton 1995; Yin 2011), studying the phenomenon of interest in its entire complexity and in relation to its context, so that unexpected relationships between variables not included in the theoretical framework can be unearthed (Yin 2011). We based our choice of cases on theoretical and convenience sampling criteria (Dubois and Gadde 2002; Halinen and Törnroos 2005; Eisenhardt and Graebner 2007). In particular, the decision to focus on design-intensive companies was due to the fact that collaboration with external knowledge sources - in this case designers - is particularly critical and strongly influences their innovation and financial performance (Capaldo 2007; Dell'Era and Verganti 2010). Moreover, the presence of influential controlling families in design-intensive companies is very common, and they are also strongly involved in the strategic and operational activities of product innovation (Craig, Dibrell, and Davis 2008; Canterino et al. 2013). Design-intensive firms are therefore an illuminating setting to unearth the relationship between family involvement and collaborative innovation (Siggelkow 2007). Applying a convenience sampling criterion, our study focuses on two design-intensive firms (B\&B Italia and Cassina), both recognised as 
innovative leaders in the furniture industry ${ }^{2}$ at the national and international level (see Table 1), and both characterised by substantial changes in the type of family involvement over time. Thus, the two cases have the 'rare and extreme' qualities appropriate for our investigation (Eisenhardt and Graebner 2007, p. 27).

(Table 1 about here)

We have been involved in several research projects with these two firms in the last few years with the broader aim of illuminating the role of design as a strategic resource for competitive advantage in design-intensive industries. The relationships established with B\&B Italia and Cassina allowed smooth interaction in the interview phase and access to secondary sources of data, such as product catalogues, press releases, and other material (Easton 1995; Dubois and Gadde 2002; Halinen and Törnroos 2005; Siggelkow 2007). Moreover, as mentioned, B\&B Italia and Cassina have undergone considerable changes in the type of family involvement over their histories. Therefore, the longitudinal analysis of the over 50 -year history of these two firms enabled reducing potential unobserved heterogeneity and more clearly focusing on how variation in the type of family involvement has influenced collaborative innovation through engagement with external designers. Finally, the focus on two designintensive family firms in the same market segment (i.e., furniture) allows ruling out alternative explanations of the phenomenon of interest caused by idiosyncratic industry dynamics (Craig et al. 2008; Canterino et al. 2013).

Of course, the results from an exploratory multiple case study analysis cannot be statistically generalised (Yin 2011). Our aim is to make analytical and theoretical

\footnotetext{
${ }^{2}$ Both companies have received several Design Awards. B\&B Italia has received 4 Compasso d'Oro Awards (1979, 1984, 1987, 1989) and Cassina 3 Compasso d'Oro Awards (1954, 1970, 1991). The Compasso d'Oro Award is the most prestigious acknowledgement dedicated to design, products, research and merit, and its international prestige is unquestioned. The Award, established in 1954, is assigned by ADI (Industrial Design Association).
} 
generalisations to the existing body of knowledge on the influence of the type of family involvement on collaborations for innovation in design-intensive family firms. Our findings are intended to inform future theoretical and empirical studies on collaboration for innovation in design-intensive family firms, and we acknowledge that they cannot be generalised to populations of firms or markets.

\subsection{Data Collection and Analysis}

We collected data on the two cases from both primary and secondary sources. In particular, we conducted twenty face-to-face interviews with key informants in the two companies between January 2015 and January 2018. Each interview lasted between 1.5 and 3 hours, and was typerecorded. The first round of interviews comprised 11 meetings with 10 informants. As this initial set of interviews unveiled interesting insights on the different collaboration practices with designers, we then organised a second wave of 9 follow-up meetings. These were aimed at digging deeper into our questions and exploring the underpinning motivation that guided the members of the family involved in the business toward different collaborations with designers. Moreover, the decision to return to and interact with the selected informants from each company was guided by our interest in collecting feedback on our ongoing interpretation of the findings. This allowed us to reinforce and confirm both our measures and the emerging body of evidence (Von Krogh, Spaeth, and Lakhani 2003). The selection of the key informants was a particularly critical step, and we chose to include both former and current managers to cover the entire history of the two firms, compare different points of view around the same topics, and reduce personal interpretation biases. For the same reasons, we also attempted to maximise the heterogeneity among interviewees (De Massis and Kotlar 2014). As Table 2 shows, the interviewees were mostly managers with strong connections with the design department of the 
two companies, the heart and engine of innovation in design-intensive firms (Dell'Era and Verganti 2009a).

(Table 2 about here)

We conducted the semi-structured interviews with the support of an interview protocol (see Appendix B for an abbreviated version), which was built around the key variables and concepts included in the theoretical framework (see Figure 1). Four classes of questions were used to frame the key concepts of the research. The first includes questions aimed at tracking the historical evolution of the company with a special focus on the temporal evolution of business and innovation aspects. The second includes questions focused on the extent of family involvement in the company's decision-making processes. The third aimed at identifying and explaining the relationship between changes in the type of family involvement and how collaborations with external designers were established and managed. Finally, the last set focuses on how the new products for each company were conceived and designed in collaboration with external designers. We pre-tested the first version of the protocol with two interviewees to check whether it was easy to understand and if the open-ended questions properly captured the different conceptual components of the framework. We derived the final version of the protocol by incorporating the feedback received in the pre-testing.

In addition to the direct interviews, we collected data from secondary sources, including official websites, in-store visits, catalogues and books, to ensure triangulation and increase internal validity (Yin 2011). Moreover, we created an internally consistent longitudinal database for each of the two cases ${ }^{3}$, which provided a chronological and detailed view of the history of the two firms in terms of new products launched and collaborations with designers. The databases map each single collaboration between the firm and an external designer. The

\footnotetext{
${ }^{3}$ The two databases are available from the authors upon request.
} 
database for B\&B Italia comprises 176 collaborations, whereas the database for Cassina includes 217 collaborations.

The analysis of the qualitative information collected through primary and secondary data sources followed established procedures. In particular, we manipulated the data before analysing them (Miles and Huberman 1984) by applying: (i) data categorisation, i.e., the decomposition and aggregation of data to highlight relevant characteristics of the family involvement in each firm and the approaches used to establish and manage collaborations with designers over time to facilitate comparison; and (ii) data contextualisation, i.e., the analysis of contextual factors that may reveal interesting relationships between the characteristics of family involvement and the approaches used to manage the collaboration with external designers. Thereafter, we conducted a within-case analysis to separately consider each case study and document the variables of interest captured in the theoretical framework. Subsequently, we applied explanation-building approaches to identify the relationship between the characteristics of the type of family involvement and the approaches used to manage the collaborations with designers. Finally, we performed a cross-case analysis to compare the patterns that emerged in each case study to obtain a general explanation of the phenomenon.

Regarding the data included in the database mapping the collaborations with external designers, we started the analysis by building appropriate metrics to operationalise the two key variables, i.e., design renewal and design identity, and calculating their values longitudinally over the history of the two firms. Design renewal measures the percentage of new designers involved in the creation and development of new products launched in a particular year $t$. Design identity focuses on the designers that have collaborated with the firm in the past, before year $t$, measured as the average value of the number of years over the entire history of the firm in which each designer collaborated with the firm. 
We calculated these two indicators to corroborate and triangulate the qualitative information collected through the interviews on temporal changes in the approaches used to establish and manage collaborations with external designers. We created these two measures as a result of the lack of indicators in the design and innovation literature to operationalise the design renewal and design identity concepts. However, with our interviewees, we were able to check the validity of these two measures in capturing and describing the different approaches used to manage collaborations with external designers in the innovation process.

\section{Results}

This section illustrates why and how changes in the type of family involvement in B\&B Italia and Cassina are associated with different approaches (captured by the two variables design renewal and design identity) used to collaborate with external designers in the innovation process. The longitudinal analysis of the two firms allowed identifying four phases into which their history can be divided. Phase 1 is characterised by the active presence of the founding family in the firm's control, Phase 2 starts with an intra-family succession leading to handing over control to the new generation of family members, Phases 3 and 4 see the entry of two private non-family investors in the governance of the two companies.

\subsection{The History of $B \& B$ Italia}

Figure 2 synthetically depicts the history of B\&B Italia, identifying the four phases mentioned above and showing the values of the two indicators, design renewal and design identity, which describe the approaches $\mathrm{B} \& \mathrm{~B}$ Italia used to involve external designers in the innovation process.

(Figure 2 about here) 
The first period in the history of B\&B Italia began in 1966 and ended in 1987. This was characterised by the leadership of the founder and head of R\&D, Piero Ambrogio Busnelli, who was always considered the engine of the firm and its innovation activities. Busnelli was directly involved in the decisions regarding which designers the firm should collaborate with and which products should be launched.

In the Research and Development group we are trained to speak with new designers, rising stars and world famous designers. The most important skill for doing this job is being open to potential new collaborations with designers. [...] We need to do our job and transform ideas into products, but everything is based on the interaction and discussion with external designers... (Federico Busnelli, $R \& D$ Director, $B \& B$ Italia, January 2015)

During Phase 1, B\&B Italia combined explorative collaborations with new designers, such as Richard Sapper and Gianfranco Ferrè (design renewal $=31.7 \%$ ), and exploitative and renewed collaborations with the same designers with the aim of defining and reinforcing product identity, such as Afra and Tobia Scarpa and Mario Bellini (design identity $=28.8 \%$ ). For example, Gianfranco Ferrè, a famous Italian fashion designer, collaborated with B\&B Italia only in 1985, creating 'Gli Abiti', a range of upholstered furniture aimed at combining design and high fashion. In the first 15 years (1966-1981), Afra and Tobia Scarpa designed 17 products that are still considered iconic today (see Figure 3).

(Figure 3 about here)

In 1988, the second generation of the Busnelli family entered the firm, with Giorgio, Giancarlo, and Emanuele becoming part of the management team. Giorgio, the eldest son with the strongest entrepreneurial outlook, took lead of the production department, Gianfranco led the contract division, and Emanuele was gradually introduced into the R\&D department. 
Therefore, the second generation took lead of the key departments of the design-intensive firm (see Figure 2). Indeed, the intra-family succession progressed over time because the founder supported his children in the subsequent ten years, taking particular care of the design process.

The succession was quite progressive, especially because Piero [1st generation family member] decided to participate in the decisions about design. He maintained leadership of $\mathrm{R} \& \mathrm{D}$ due to his passion for design and innovation... (Maurizio Mazzucchelli, General Manager B\&B Italia, February 2015)

In Phase 2 (1998-2002), the value of the design renewal indicator significantly decreased $($ design renewal $=24.4 \%)$, while design identity remained roughly constant $($ design identity $=$ $28.3 \%$ ). These dynamics can be partly explained by B\&B Italia's strategic decision to exploit to the greatest extent the impressive designer portfolio created in Phase 1. Furthermore, in the same period, B\&B Italia established additional collaborations with historical designers with whom the firm had collaborated in the past, significantly contributing to reinforcing product identity. This was mainly guided by the controlling family's aim to protect the family tradition and reinforce the identity and reputation of the family name, which was strongly associated with the identity of its new products (De Massis et al. 2016; Gomez-Mejia et al. 2007). Afra and Tobia Scarpa were progressively replaced by Antonio Citterio, who would become the most important designer in the subsequent decades.

The third phase began in 2003 and ended in 2008 (see Figure 2). In 2003, the venture capital fund Opera I (owned by Opera Società di Gestione del Risparmio - SGR ${ }^{4}$ ) acquired a majority share (51.4\%). The fund had in its portfolio companies such as Bulgari and other highend Italian fashion firms. This considerably influenced the behaviour and attitude of the fund toward $\mathrm{B} \& \mathrm{~B}$ Italia, as the expertise of the venture capital fund was more in fashion than in

\footnotetext{
${ }^{4} \mathrm{SGR}$ is the Italian acronym for authorized asset management. Established with Italian Legislative Decree No. 58 of 24 February 1998, asset management companies are joint stock companies that invest savings collected through mutual funds.
} 
design-intensive furniture. In Phase 3, the value of the two indicators changed significantly: while design renewal increased, design identity decreased. On the one hand, the venture capital fund steered attention toward short-term goals. As a consequence, B\&B Italia developed several collaborations with new and famous designers, such as Naoto Fukasawa, Zaha Hadid, JeanMarie Massaud, Patricia Urquiola, and Marcel Wanders (design renewal $=32.9 \%$ ), with the aim of significantly refreshing its image in the market and quickly launch products designed to achieve immediate market success (see Figure 4). Thus, the change in the coalition controlling the firm - from the family to the fund - reduced the long-term orientation of the family firm and led to prioritising short-term versus long-term goals (Lumpkin and Brigham 2011; De Massis et al. 2018). On the other hand, design identity significantly decreased due to the reduced influence and participation of the family in collaborating with historical designers (design identity $=20.7 \%$ ). With some exceptions, such as Mario Bellini and Paolo Piva, product identity was mainly nurtured through the collaboration with Antonio Citterio, who designed around $50 \%$ of the products in the period 2003-2008 (59 products out of 125). This was mainly due to the newly controlling fund's desire to weaken the ties with the firm's tradition (De Massis et al. 2016) so as to facilitate prioritising short-term business-centred goals.

(Figure 4 about here)

Phase 4 began in 2009 and was characterised by a change in the private equity fund (see Figure 2). Michele Russo took lead of Opera I over Renato Preti, former Chief Executive Officer of Opera, and redefined the fund's strategy, changing the advisory board and hiring new managers. Hence, there was a change in the involvement in management, as the management team no longer consisted of a large majority of family members, although the newly recruited managers continued to recognise the importance of family values in directing the overall firm's efforts. Therefore, this second period in which the private equity fund was involved in $\mathrm{B} \& \mathrm{~B}$ 
Italia was characterised by a higher propensity toward incremental innovations, consistent with the typical parsimony characterising family values (Carney 2005), rather than toward maximising short-term performance. Indeed, while the first fund did not have expertise in the design industry, the second team of professional managers recruited by Opera SGR in B\&B Italia was completely different. More specifically, Opera SGR brought in a former manager from BTicino, a leading Italian company globally renowned for innovation, quality, technology, and design. The CEO's background had a strong and completely different impact on strategic decisions. In this last phase, the design management practices adopted in the collaborations with designers changed again, with a significant decrease in the value of the design renewal indicator and an increase in design identity. The strategy that the new private equity fund adopted was to really enter into the new product development process, strengthening the role of its managers in the decision-making process. This was managed by continuously leveraging the collaboration with the family, considered more as advisory experts than real decision-makers, by adopting a type of family involvement that gradually reduced the influence of family members in shaping the new collections. In particular, the main advisory role was left to Giorgio Busnelli, whereas his sons were involved in the industrial and contract divisions. Although the overall management of the firm was in the hands of Stefano Ferro, the new managing director that Opera SGR brought in, the attitude of the private equity fund toward the firm also changed in this phase.

What was not good in B\&B Italia in 2009 was the fact that its bestseller was the Charles sofa designed twelve years before. [...] We changed things with respect to the previous fund; the goal was to produce products that could remain in the market for several years and it was clear that the family expertise was needed, but as a leading manager I needed to really make decisions on my own... (Stefano Ferro, CEO B\&B Italia brought in by Opera II, March 2015) 
Exploration through collaborations with new designers, such as Gabriele and Oscar Buratti, Edward Barber, and Jay Osgerby, was limited to a few projects $($ design renewal $=11.3 \%)$, while most collaborations involved historical designers, such as Antonio Citterio, Jeffrey Bernett, Naoto Fukasawa, Paolo Piva, and Patricia Urquiola (design identity $=23.8 \%$ ). Antonio Citterio designed $70 \%$ of the products in the period 2009-2012 (57 products out of 81 ).

\subsection{The History of Cassina}

Figure 5 shows a synthetic description of the history of Cassina, illustrating the four phases of its history and the values of the design renewal and design identity indicators over time.

(Figure 5 about here)

Cassina was founded in 1927, but the company became a real design-intensive firm in 1960 by establishing numerous collaborations with designers and architects. The longitudinal analysis hence focused on the period 1960 to 2015. The first period (1960-1973) was particularly glorious to the point that, in 1970, the company received a Compasso d'Oro (the most prestigious design award from ADI, see Footnote 2) and started collaborating with renowned designers, such as Afra and Tobia Scarpa, and Vico Magistretti. The latter particularly influenced the firm and some of his products quickly became recognised as masterpieces in the market. In two decades, thanks to the visionary leadership of the founders (Cesare and Umberto Cassina), the firm changed from an artisanal and mostly regional company to an international icon in the furniture industry. Although both the founders were under thirty years old when they created the company, due to their skills and capabilities, Cassina immediately became famous worldwide for its woodworking furniture. After many years of artisanship, the firm became a global supplier of furniture for transatlantic vessels, such as the Andrea Doria in 1947. Even if in the first 14 years, until 1974, Cassina on average 
established over a quarter of its collaborations with new designers (design renewal $=28.5 \%$ ), the design management practices were characterised by intense collaborations with three designers who significantly influenced product identity (Carlo De Carli, Gianfranco Frattini, and Ico Parisi, who developed 40 products out of 115 in Phase 1), and two designers who joined the company respectively in 1963 and 1967 (Vico Magistretti and Mario Bellini, developing 27 products out 115 in Phase 1; design identity =61.8\%) (see Figure 6).

(Figure 6 about here)

The second phase began in 1974 and ended in 1988 (see Figure 5). This period was characterised by the shift from the first to the second-generation family members. In particular, Franco Cassina, Umberto's son, and Rodrigo Rodriquez, Cesare's son-in-law, entered the company as general co-directors. Under their leadership, the company was structured into departments and business units. In this period, the artisan company turned into the professionalised organisation it is today. In Phase 2, the value of the design renewal indicator marginally increased compared to Phase 1 (design renewal $=30.5 \%)$, while the value of design identity significantly decreased (reaching $22.2 \%$ ). Even if some collaborations with historical designers, such as Mario Bellini, Gianfranco Frattini, and Vico Magistretti, remained in place in Phase 2, Cassina significantly reframed its identity through introducing the product line 'I Maestri', acquiring the sketches from famous designers, such as Le Corbusier and Frank Lloyd Wright. This strategic decision, in terms of portfolio management, influenced future products, as Rodrigo Rodriquez explained.

The creation of I Maestri was a strategic choice that influenced our future. Indeed, collaborating with foundations and heirs created a strong collaboration between Cassina and the work of the architects of the past, setting the standard for our future products... (Rodrigo Rodriquez, Cassina, February 2015) 
The decrease in design identity is consistent with some family business studies arguing that intra-family succession typically leads the new generation family leader to diverge from the identity and goals of the previous generation (e.g., Kotlar and De Massis 2013), distinguishing between lone founder and later-generation family firms (e.g., Miller et al. 2007; Le BretonMiller and Miller 2008). Our finding instead contrasts other studies on the 'founder's shadow' and the overall tendency of family members to continue the tradition of their predecessors (e.g., Davis and Harveston 1999; De Massis et al. 2016).

The third period began in 1989, when the French fund Strafor-Facom acquired Cassina. In particular, the second-generation family members, Franco Cassina and Rodrigo Rodriquez, were concerned that a company with two leaders would be difficult to manage and thus sought and found an external investor, namely, Strafor-Facom. Although the French group was itself a global manufacturing company, and not a private equity fund, it acted purely as an investor without absorbing or integrating Cassina into its existing operations. This is the reason why Strafor-Facom can be considered a private equity fund in its relationship with Cassina. Acting as a pure fund, Strafor-Facom looked mostly at the firm's current and projected financial results. The second-generation family members handed over control of the company to the French Group, while the third generation covered management and operational roles. Umberto, Franco Cassina's son, joined the company and became the reference point for strategic R\&D decisions and for the development of the product portfolio. Moreover, he started working closely with the Strafor-Facom managers. The French Group decided to hire an R\&D director and other managers to continue professionalising the firm. This notwithstanding, Strafor-Facom was not highly involved in the strategic decision-making process since, as explained above, it exercised its control mainly through the analysis of financial results without interfering in dayto-day decisions. The design management approach in the collaborations with external designers significantly changed in Phase 3 . On the one hand, the short-term strategy of the 
French Group was based on developing collaborations with new and famous designers, such as Francesco Binfarè, Piero Lissoni, Ettore Sottsass, and Philippe Starck (design renewal = 43.9\%). On the other hand, they collaborated in a limited way with historical designers, such as Vico Magistretti (design identity $=10.2 \%$; see Figure 7).

(Figure 7 about here)

The change in the coalition controlling Cassina from the family to the fund led to the same change in the collaborative innovation approach as that in B\&B Italia, i.e., an increase in design renewal and a decrease in design identity, and similar motivations for such change emerged from the two cases. In particular, the increase in design renewal appeared to be mainly guided by the newly controlling fund's aim to prioritise short-term goals rather than the long-term goals of the controlling family (Lumpkin and Brigham 2011; De Massis et al. 2018), which led to increasing collaborations with new and famous designers with the aim of significantly refreshing the family firm's image in the market and to quickly launch products designed to achieve immediate market success. On the other hand, the decrease in design identity appeared to be driven by the newly controlling fund's desire to weaken the ties with the firm's tradition (De Massis et al. 2016) so as to facilitate prioritising the short-term business-centred goals, thereby reducing family influence and participation in collaborating with historical designers.

The fourth phase began in 2006 and ended in 2015 (see Figure 5). This differed completely from the previous phases, as the third generation of the founding family sold the company to the Italian venture capital fund Charme. This notwithstanding, the family members stayed in the company as managers, especially with a focus on new product development. The fund was intentionally created in 2003 to take lead of Poltrona Frau, an Italian luxury brand in the furniture market. After three years, Charme acquired 100\% of Cassina. The fund's aim was to take the company to IPO (Initial Public Offering). From a managerial perspective, a new brand director with unlimited control of all the business units was nominated. In particular, the brand 
directors were Demetrio Apolloni in a first period and Gianluca Armento from 2009. The venture capital fund's strategy was to introduce a structured approach to managing external collaborations.

Today we manage the designer portfolio in a very structured way. We rely on 3 or 4 historical designers who have collaborated with us for many years, 3 or 4 junior designers who have collaborated with us once or twice, and finally, 2 or 3 completely new designers... (Gianluca Armento, Brand Director Cassina, February 2015)

The value of the design renewal indicator decreased to $21.5 \%$, while the value of design identity remained in line with the previous period (design identity $=9.8 \%$ ). Cassina established a few collaborations with new designers, such as Rodolfo Dordoni, Konstantin Gricic, Luca Nichetto, and maintained its product identity through collaborations with historical designers, such as Philippe Starck and Piero Lissoni. The decrease in design renewal emerged as mainly due to the aim of the non-family top management team recruited by the venture capital fund to halt the family managers' tendency of growing the network of new designers involved in the creation and development of new products. In Demetrio Apolloni's words:

It was clear that we should have focused more on collaborations with designers with whom we have already developed a relationship in the past rather than continuing look for new designers and new collaborations. The family in the past had rashly pushed for collaboration with new designers in order to pursue their goal to increase the family reputation. We, instead, attach more importance to profits than to just reputation! (Demetrio Apolloni, Brand Director Cassina, October 2017)

\subsection{Summary of the Key Findings}


Our qualitative account highlights some interesting recurrent patterns in the two case studies that illuminate the effects of the type of family involvement in design-intensive family firms on how they collaborate with external designers in the innovation process.

First, in both B\&B Italia and Cassina, the strong involvement of the founding family in the firm's control is associated with higher levels of design identity. This aspect clearly emerges in Phase 1 for both firms (design identity $=61.8 \%$ in Cassina, and $28.8 \%$ in B\&B Italia), especially when compared to the other phases. Our analysis suggests this is due to the strong importance the founding family members placed on building and reinforcing a consistent family identity (Berrone, Cruz, and Gomez-Mejia 2012; De Massis et al. 2016; Gomez-Mejia et al. 2007), even if this potentially undermined short-term performance. This entailed the continuous involvement of a relatively small and select number of external designers in the innovation process. As two interviewees stated:

Both the founder and his successor believed that the collaboration with historical designers represented a fundamental practice in order to transform B\&B Italia into an iconic brand whose products can be clearly and easily recognised by consumers... (Carlo Magistretti, Industrial Director B\&B Italia, January 2018)

The collaboration with historical designers and the development of the product line 'I Maestri' represent two different initiatives aimed at conveying a clear product identity to the market... (Gianluca Armento, Brand Director Cassina, October 2017)

Second, albeit linked to the first point, the adoption of a type of family involvement characterised by reduced influence and control exerted by family members, particularly with the entry of a professional investment fund, generated an increase in the value of the design renewal indicator. This can be explained by the fact that the non-family owners were more interested in prioritising short-term performance instead of maximising socio-emotional wealth 
through preserving and strengthening product identity. Preserving socio-emotional wealth is one of the primary goals of family-firms (Berrone et al. 2012), usually linked to the pursuit of family-centred non-economic goals, such as preserving the family's identity or maintaining a strong tie between the family and the company name. This might lead to investments that are not aligned and fully justified by a pure business-oriented strategy, instead more guided by a sense of attachment to the family dynasty. Moreover, the literature shows that succeeding generations may take decisions that might not be profitable in the short-term but are motivated by the willingness to provide continuity to the brand's existence (De Massis et al. 2014b; Cannella, Jones, and Withers 2015). Although these are vital drivers for family managers, they are not as relevant for non-family managers. Put differently, the change in the coalition controlling the firm from the family to the fund reduced the long-term orientation of the family firm and led to prioritising short-term versus long-term goals (Lumpkin and Brigham 2011; De Massis et al. 2018). Thus, greater emphasis was placed on creating radically new products by involving several new external designers to produce tangible and positive results. This is clear when considering, for instance, the following statement:

In the first years following the acquisition by the venture capital fund, many concepts developed by new, emergent, and international designers were proposed to the R\&D department. We were looking for fresh ideas and new stars that could provide immediate market benefits... (Federico Busnelli, $R \& D$ Director, $B \& B$ Italia, May 2015)

Third, the findings suggest that intra-family succession and the involvement of subsequent generations of family members is associated with a decrease in the value of design identity. This pattern is particularly clear in Cassina. Each phase in the firm's history until 2006 was characterised by intra-family succession, and the value of design identity decreased from $61.8 \%$ in Phase 1 to $10.2 \%$ in Phase 3. This is consistent with prior research suggesting that as family 
firms move from the first to subsequent generations, they become more focused on pursuing economic goals and less on maintaining family control or other types of non-economic goals, such as family identity (Cannella et al. 2015; Gomez-Mejia et al. 2007). Moreover, family members from the first generation are more risk-averse compared to later generations (Kellermanns and Eddleston 2006). As a result, firms characterised by the involvement of second- and third-generation family members are more prone to explore new relationships with external designers, even if this may put product identity at risk, in the attempt to generate highly successful new products that produce short-term and high economic returns. This finds confirmation in the words of Gianluca Armento, Brand Director at Cassina:

While the vision pursued by the Cassina founders mainly aimed at defining a precise product identity based on collaboration with few designers, their successors developed a different strategy involving several designers with the aim of exploring new product languages and consequently targeting new customers ... (Gianluca Armento, Brand Director Cassina, October 2017)

Finally, our analysis points to the existence of a relationship between changes in the involvement of family members in management and changes in the approach used to create new products through collaborations with external designers. In particular, this relationship becomes clear only regarding the design renewal variable. As a consequence of changes in the involvement of family members in management, the design renewal value decreased. This is evident both in Cassina and in B\&B Italia. In Phase 4 in both cases, when there was a change from mainly family members involved in management to a management team mainly composed of non-family members professionally recruited by the funds, the value of design renewal dropped. On the one hand, our qualitative evidence reveals that this is due to the aim of the nonfamily top management team recruited by the venture to halt the family managers' tendency to grow the network of new designers involved in the creation and development of new products. 
On the other hand, the decrease in design renewal can be ascribed to managerial complexity in nurturing and managing two very different categories of collaborations: those with historical designers based on consolidated practices, and those with new designers requiring new approaches and modalities (Capaldo 2007; Dell'Era and Verganti 2007). For instance, one of our interviewees recognised:

Even if the mix between historical and new designers allowed balancing the tradeoff between exploitation and exploration, it implied significant complexity from a managerial point of view. Continuously refreshing the designer portfolio needs to be carefully evaluated considering the relationship costs this implies ... (Gianluca Armento, Brand Director Cassina, October 2017)

\section{Discussion, Implications and Limitations}

This longitudinal qualitative analysis sheds light on the relationship between changes in the type of family involvement in design-intensive family firms as it evolves over time and the approaches they use to generate product innovations by collaborating with external designers. In particular, our qualitative study identifies new and thus far unexplored effects of the characteristics of different types of family involvement in family firms (as captured by the extent to which the family is involved in the firm's control, the generation of family members, and the family's involvement in management), and the approaches used to collaborate with external designers, captured along two variables measured with the design identity and design renewal indicators.

Our findings: (i) respond to recent calls from family business scholars to consider that the characteristics of family involvement in a family firm can change over time (Gersick 1997), and that their influence on firm behaviour can therefore vary over time (e.g., Sharma et al. 2014). Moreover, the results advance current knowledge by pointing out the important role of the type of family involvement in the firm's control, generation, and management as drivers 
influencing the innovation behaviours in family firms (Chrisman et al. 2015a); (ii) address recent calls to understand collaborative innovation in family firms (Feranita et al. 2017), providing a detailed qualitative account suggesting that the extent of family involvement is not enough to understand collaborative innovation in family firms (Chrisman et al. 2015b), which also requires understanding the type of family involvement as captured by family control, generation, and management; and (iii) offer a rich body of evidence on the temporal evolution of family firm behaviour (Sharma et al. 2014; De Massis et al. 2014a), particularly revealing some mechanisms in relation to why and how the evolution of the type of family involvement in a family firm influences how product innovation is generated.

The main contributions of this study are discussed hereafter. First, by qualitatively exploring how the approaches to collaborating with external designers changed in response to evolutions in the type of family involvement in the two design-intensive family firms in our sample, our empirical results advance current understanding of how innovation takes place in family firms, which is a rather neglected aspect in existing literature (De Massis et al. 2013, 2015b). Extant research mainly focuses on the inputs and outputs of innovation processes in family firms (Duran et al. 2016), without thoroughly shedding light on the anatomy of innovation processes in family firms in their entire complexity, something this qualitative study attempts to do. Second, we advance knowledge on the determinants of heterogeneity among family firms. Our findings outline the characteristics of the different types of family involvement (as identified by the family control, generation, and management dimensions) and their variations over time as important sources of heterogeneity of family firm behaviour. Thus, the findings of our qualitative analysis respond to recent calls to consider the heterogeneity across family firms in studying their idiosyncratic behaviours (Chua et al. 2012; De Massis et al. 2014b) and to adopt a more contextualised approach to understand their innovation decisions and actions (e.g., Chrisman et al. 2015a), especially when family business innovation takes 
place through collaborations with external parties (e.g., Casprini et al. 2017; Lambrechts et al. 2017). In this respect, our study's findings suggest some recurrent patterns that illuminate the effects of the characteristics of the different types of heterogeneous family involvement in design-intensive family firms on collaborating with external designers, thereby contributing to uncovering an important determinant of heterogeneity in collaborative innovation behaviours across design-intensive family firms. Moreover, the analysis of the two cases enriches current understanding of 'within family firm' heterogeneity. Indeed, control, generation, and management are three important dimensions characterising the different types of family involvement, and our study's findings illustrate that the type of family involvement can also vary over time within the same family firm. Thus, we challenge prior research on family business heterogeneity, which has mainly focused on understanding variations across different types of family firms, paving the way for future research that looks at heterogeneity both within the same family firm and across different family firms. Finally, by clarifying how variations in type of family involvement affect the practices adopted to manage the relationship with external designers in innovation (synthetically captured with the two indicators, design renewal and design identity), our findings contribute to existing literature on innovation in design-intensive firms, which has thus far overlooked the 'family' variable despite that the vast majority of companies in design-intensive industry are family firms (Dalpiaz et al. 2014).

\subsection{Theoretical Implications}

These considerations have important implications for advancing our theoretical understanding of the family enterprise, particularly in the area of innovation, and provide promising directions for future studies. More precisely, researchers have only recently started to focus on the governance system of organisations as a possible antecedent of their innovation behaviour (Chrisman et al. 2015a; De Massis et al. 2015a), and this study adds to the embryonic 
knowledge on this topic, responding to recent calls to delve deeper into the family heterogeneity dimensions when examining family firm behaviour (Rondi, De Massis, and Kotlar 2018).

One of the most important implications of our qualitative study is that the type of family involvement in a business organisation can vary over time, and such variations seem to produce changes in how innovation is created. Considering the time-varying nature of family involvement in a (family) firm may thus enable understanding the way innovation is managed. Accordingly, we encourage scholars to further analyse how family control, generation, and management change over time, and how such changes influence innovation decisions, a topic that has received only scant attention both conceptually and empirically.

Researchers wishing to continue with this line of enquiry could further assess the nature of this complex relationship by investigating how other configurations of family control, generation, and management influence innovation processes, and how these are managed. Moreover, in examining the design management approaches used to create innovation, we focus here on design identity and design renewal. However, as Ravasi and Stigliani (2012) underline, other aspects could be included in future investigations aimed at developing a better understanding of design management approaches. Moreover, it would be interesting to analyse the influence of different management approaches linked to changes in type of family involvement on design performance, such as the number of design awards received in a multiindustry setting. Furthermore, a deeper understanding of how different characteristics of family involvement influence the creation of innovation of meanings will hopefully expand our knowledge of design-driven innovation processes (Verganti 2009). Finally, this paper has developed and applied two new indicators to capture different strategic approaches to the management of collaborative relationships with external designers in design-intensive firms. Hopefully, these indicators will inform and be used in future large-scale quantitative 
investigations on the management of innovation in design-intensive firms, thereby receiving extensive testing and corroboration.

\subsection{Managerial and Policy Implications}

This study also has some interesting practical implications. The most important is highlighting that the innovation strategy of a design-intensive family firm and the approaches used to involve external designers are influenced by the characteristics of the family involvement type. Therefore, a certain innovation strategy and approach to involving external designers may not be applicable (or would likely face strong barriers in their implementation) if inconsistent with the characteristics of the firm's type of family involvement. This points to the importance, consistent with the concept of family-driven innovation (De Massis et al. 2015a), that designintensive family firms make strategic decisions in innovation in line with the idiosyncratic characteristics of their governance structure. These characteristics (in particular, control, generation, and management, as highlighted in this paper) should therefore be considered and properly analysed in the strategic decision-making process. Moreover, our findings caution against the risk of losing or at least weakening the family firm's identity when the founding family members' involvement is reduced due to intra-family succession or the entry of professional investment funds. Under these conditions, finding the proper balance between pursuing short-term goals by creating radically new products through collaborating with new designers, and preserving the family identity through collaborating with familiar designers, may be an important aspect and may require purposefully crafted solutions. Organisational ambidexterity could be a viable approach in this regard (Tushman and O'Reilly 1996).

Regarding policy implications, this study first highlights the importance of collaborations with designers aimed at creating and developing new products in design-intensive family firms. Policies designed to foster innovativeness, competitiveness, and growth of family businesses 
operating in these industries should therefore carefully consider this aspect. Furthermore, this paper points to the important influence that different characteristics associated with different types of family involvement have on the strategic behaviour of family firms. Therefore, policy makers should consider that the ability of different policy initiatives to promote strategic behaviours leading to superior competitive advantage is likely influenced by the idiosyncratic characteristics of the family business. This highlights the importance of considering more tailored-made and customised policy support for family firms.

\subsection{Limitations}

Like all studies, our work has some limitations that provide opportunities for future research. First, given the methodology used, this study does not allow for statistical generalisation, for example, inferring conclusions about a population (Harrison and Kjellberg 2010). Indeed, we aim to make analytical generalisations from empirical evidence to theory (e.g., Yin 2011). Put differently, our case study evidence allows a new theoretical understanding of the effect of type of family involvement in a family firm and the approaches to creating innovation through collaboration with external designers. We encourage scholars to employ quantitative methods to statistically test in large-scale studies some of the relationships that emerged in our qualitative investigation. Ideally, such studies would be longitudinal to ensure capturing the cause-effect and temporal relationships between variations in the ownership structure and the design management practices adopted to create innovations. Second, our convenience sample is drawn from one country (Italy). We encourage scholars to add evidence from other countries to ensure that the effects found are not linked to Italian institutional or cultural variables. For instance, innovation management may be specifically bounded to cultural contingencies. Finally, our study focuses on two design-intensive firms in the furniture industry, but we recognise that the industrial sector may play a crucial role in shaping the phenomenon under 
investigation (De Massis et al. 2018), and hence encourage future scholars to conduct crossindustry investigations of design-intensive firms in other sectors, such as fashion, lighting, and kitchenware.

\section{Conclusion}

This study illuminates the relationship between the type of family involvement in a designintensive family firm and the approaches to collaborating with external designers in product innovation. It does so by studying the longitudinal cases of two Italian furniture companies, i.e., B\&B Italia and Cassina. The findings of our qualitative account: (i) emphasise the importance of considering the type rather than merely the degree of family involvement in an organisation, and variations thereof, in innovation studies; (ii) suggest why and how the approaches that design-intensive family firms use to innovate through collaborating with designers are subject to change as the type of family involvement evolves over time; and (iii) provide some important insights for family firm managers, consultants, and policymakers interested in unlocking the innovation potential of family firms. This paper also points to the importance of adopting a temporal perspective in family business research, considering the heterogeneity among family firms and employing a more contextualised approach to develop more complete and accurate understanding of innovation processes in family firms, and particularly their determinants and outcomes. Hopefully, this work will inform future theoretical and empirical research at the intersection of design, innovation, and family business studies.

\section{References}

Berrone, P. Cruz, C., and Gomez-Mejia, L. R. 2012. "Socioemotional wealth in family firms. theoretical dimensions, assessment approaches, and agenda for future research." Family Business Review 25 (3) 258-279.

Bertola, P., and Texeira J. C. 2003. "Design as a knowledge agent: How design as a knowledge process is embedded into organizations to foster innovation." Design Studies 24 (2): 181194. 
Beverland, M. B. 2005. "Crafting brand authenticity: The case of luxury wines." Journal of Management Studies 42 (5): 1003-1029.

Block, J. H., and Spiegel, F. 2013. "Family firm density and regional innovation output: An exploratory analysis". Journal of Family Business Studies 4 (4): 270-280.

Borja de Mozota, B. 2004. Design Management: Using Design to Build Brand Value. Allworth Press Borja.

Brown, T. 2008. "Design thinking." Harvard Business Review 86 (6): 84.

Buchanan, R. 2001. "Human dignity and human rights: Thoughts on the principles of humancentered design." Design Issues 17 (3): 35-39.

Calabrò, A., Vecchiarini, M., Gast, J., Campopiano, G., De Massis, A., and Kraus, S. 2018. "Innovation in family firms: A systematic literature review and guidance for future research." International Journal of Management Reviews, in press. DOI:10.1111/ijmr.12192.

Cannella, A. A., Jones, C. D., and Withers, M. C. 2015. "Family- versus lone foundercontrolled public corporations: Social identity theory and boards of directors." Academy of Management Journal 58 (2): 436-459.

Canterino, F. Cirella, S. Guerci, M. Shani, A. B., and Brunelli, M. S. 2013. "Leading transformation in a family-owned business: insights from an Italian company." International Journal of Entrepreneurship and Innovation Management 17 (1-3): 54-83.

Capaldo, A. 2007. "Network structure and innovation: The leveraging of a dual network as a distinctive relational capability." Strategic Management Journal 28 (6): 585-608.

Carney, M. 2005. "Corporate governance and competitive advantage in family-controlled firms." Entrepreneurship Theory and Practice 29 (3): 249-266.

Casprini, E. De Massis, A. Di Minin, A. Frattini F., and Piccaluga, A. 2017. "How family firms execute open innovation strategies: The Loccioni case." Journal of Knowledge Management 21 (6): 1459-1485.

Chrisman, J. J., Chua, J. H., De Massis, A., Frattini, F., and Wright, M. 2015a. "The ability and willingness paradox in family firm innovation." Journal of Product Innovation Management 32 (3): 310-318.

Chrisman, J. J., Fang, H., Kotlar, J., and De Massis, A. 2015b. "A note on family influence and the adoption of discontinuous technologies in family firms." Journal of Product Innovation Management 32 (3): 384-388.

Chua, J. H., Chrisman, J. J., and Sharma, P. 1999. "Defining the family business by behaviour." Entrepreneurship: Theory and Practice 23 (4): 19-19.

Chua, J. H., Chrisman, J. J., Steier, L. P., and Rau, S. B. 2012. "Sources of heterogeneity in family firms: An introduction." Entrepreneurship Theory and Practice 36 (6): 1103-1113.

Cillo, P., and Verona, G. 2008. "Search styles in style searching: Exploring innovation strategies in fashion firms." Long Range Planning 41 (6): 650-671.

Classen, N. Gils, A. Bammens, Y., and Carree, M. 2012. "Accessing resources from innovation partners: The search breadth of family SMEs." Journal of Small Business Management 50 (2): 191-215.

Craig, J. B., Dibrell C., and Davis, P. S. 2008. "Leveraging family-based brand identity to enhance firm competitiveness and performance in family businesses." Journal of Small Business Management 46 (3): 351-371. 
Craig, J. B., Pohjola, M., Kraus, S., and Jensen, S. H. 2014. "Exploring relationships among proactiveness, risk-taking and innovation output in family and non-family firms." Creativity and Innovation Management 23 (2): 199-210.

Cruz, C., and Nordqvist, M. 2012. "Entrepreneurial orientation in family firms: A generational perspective." Small Business Economics 38 (1): 33-49.

Dalpiaz, E., Rindova, V., and Ravasi, D. 2016. "Combining logics to transform organizational agency: Blending industry and art at Alessi." Administrative Science Quarterly 61 (3): 347392.

Dalpiaz, E., Tracey, P., and Philips, N. 2014. "Succession narratives in family business: The case of Alessi." Entrepreneur Theory and Practice 38 (6): 1375-1394.

Davis, P.S., and Harveston, P. D. 1999. "In the founder's shadow: Conflict in the family firm." Family Business Review 12 (4): 311-323.

De Massis, A. Audretsch, D., Uhlaner, L., and Kammerlander, N. 2018. "Innovation with limited resources: Management lessons from the German Mittelstand." Journal of Product Innovation Management 35 (1): 125-146.

De Massis, A., Chirico, F., Kotlar, J., and Naldi, L. 2014a. "The temporal evolution of proactiveness in family firms: The horizontal S-curve hypothesis." Family Business Review 27 (1): 35-50.

De Massis, A., Di Minin, A., and Frattini, F. 2015a. "Family-driven innovation: Resolving the paradox in family firms." California Management Review 58 (1): 5-19.

De Massis, A. Frattini, F., Kotlar, J., Messeni-Petruzzelli, A., and Wright M. 2016. "Innovation through tradition: Lessons from innovative family businesses and directions for future research." Academy of Management Perspectives 30 (1): 93-116.

De Massis, A., Frattini, F., and Lichtenthaler, U. 2013. "Research on technological innovation in family firms: Present debates and future directions." Family Business Review 26 (1): 1031.

De Massis, A., Frattini, F., Pizzurno, E., and Cassia, L. 2015b. "Product innovation in family versus nonfamily firms: An exploratory analysis." Journal of Small Business Management 53 (1): $1-36$.

De Massis A., and Kotlar, J. 2014. "The case study method in family business research: Guidelines for qualitative scholarship.” Journal of Family Business Strategy 5 (1): 15-29.

De Massis A., Kotlar J., Chua, J. H., and Chrisman J. J. 2014b. "Ability and willingness as sufficiency conditions for family-oriented particularistic behavior: Implications for theory and empirical studies." Journal of Small Business Management 52 (2): 344-364.

De Massis, A., Kotlar, J., Frattini, F., Chrisman, J. J., and Nordqvist, M. 2016. "Family governance at work organizing for new product development in family SMEs." Family Business Review 29 (2): 189-213.

Dell'Era, C., Altuna, N., Magistretti, S., and Verganti, R. 2017. "Discovering quiescent meanings in technologies: Exploring the design management practices that support the development of Technology Epiphanies." Technology Analysis \& Strategic Management 29 (2): $149-166$.

Dell'Era, C., Magistretti, S., and Verganti, R. 2018. "Exploring collaborative practices between SMEs and designers in the Italian furniture industry." In Vanhaverbeke, W., Frattini, F., Roijakkers, N., and Usman, M. (eds) Researching Open Innovation in SMEs, World Scientific Publishing Co., pp. 307-345. 
Dell'Era, C., Marchesi, A., and Verganti, R. 2008a. "Linguistic network configurations: Management of innovation in design-intensive firms." International Journal of Innovation Management 12 (1): 1-19.

Dell'Era, C., Marchesi, A., Verganti, R., and Zurlo, F. 2008b. "Language mining: Analysis of the innovation of dominant product languages in design-intensive industries." European Journal of Innovation Management 11 (1): 25-50.

Dell'Era, C., and Verganti, R. 2007. "Strategies of innovation and imitation of product languages." Journal of Product Innovation Management 24: 580-599.

Dell'Era, C., and Verganti, R. 2009a. "Design-driven laboratories: Organization and strategy of laboratories specialized in the development of radical design-driven innovations." $R \& D$ Management 39 (1): 1-20.

Dell'Era, C., and Verganti, R. 2009b. "The impact of international designers on firm innovation capability and consumer interest." International Journal of Operations \& Production Management 29 (9): 870-893.

Dell'Era, C., and Verganti, R. 2010. “Collaborative strategies in design-intensive industries: Knowledge diversity and innovation.” Long Range Planning 43 (1): 123-141.

Dell'Era C., and Verganti R. 2011. "Diffusion processes of product meanings in designintensive industries: Determinants and dynamics." Journal of Product Innovation Management 28: 881-895.

D'Ippolito, B. 2014. "The importance of design for firms' competitiveness: A review of the literature." Technovation 34 (11): 716-730.

Dubois, A., and Gadde, L. E. 2002. "Systematic combining: An abductive approach to case research." Journal of Business Research 55 (7): 553-560.

Duran, P., Kammerlander, N., Van Essen, M., and Zellweger, T. 2016. "Doing more with less: Innovation input and output in family firms." Academy of Management Journal 59 (4): 1224-1264.

Durgee, J. F. 2006. "Freedom for superstar designer? Lessons from art history." Design Management Review 17 (3): 28-34.

Easton, G. 1995. "Case research as a methodology for industrial networks: A realist apologia." IMP Conference 11.

Eisenhardt, K. M. 1989. "Building theories from case study research." Academy of Management Review 14 (4): 532-550.

Eisenhardt, K. M., and Graebner, M. E. 2007. "Theory building from cases: Opportunities and challenges." Academy of Management Journal 50 (1): 25-32.

Feranita, F. Kotlar, J., and De Massis, A. 2017. "Collaborative innovation in family firms: Past research, current debates and agenda for future research." Journal of Family Business Strategy 8 (3): 137-156.

Filser, M., De Massis, A., Gast, J., Kraus, S., and Niemand, T. 2017. "Tracing the roots of innovativeness in family SMEs: The effect of family functionality and socioemotional wealth." Journal of Product Innovation Management 35 (4): 609-628.

Gedajlovic, E., Lubatkin, M., and Schulze, W. 2004. "Crossing the threshold from founder management to professional management: A governance perspective." Journal of Management Studies 41 (5): 899-912.

Gersick, K. E. 1997. Generation to Generation: Life Cycles of the Family Business. Boston: Harvard Business Press. 
Gómez-Mejía, L. R., Haynes, K. T., Núñez-Nickel, M., Jacobson, K. J., and Moyano-Fuentes, J. 2007. "Socioemotional wealth and business risks in family-controlled firms: Evidence from Spanish olive oil mills." Administrative Science Quarterly 52 (1): 106-137.

Gulati, R. 1998. “Alliances and networks.” Strategic Management Journal 19 (4): 293-317.

Halinen, A., and Törnroos, J. A. 2005. "Using case methods in the study of contemporary business networks." Journal of Business Research 58 (9): 1285-1297.

Harrison, D., and Kjellberg, H. 2010. "Segmenting a market in the making: Industrial market segmentation as construction." Industrial Marketing Management 39 (5): 784-792.

Howorth, C., Westhead, P., and Wright, M. 2004. "Buyouts, information asymmetry and the family management dyad." Journal of Business Venturing 19 (4): 509-534.

Karjalainen, T. M., and Snelders D. 2010. "Designing visual recognition for the brand." Journal of Product Innovation Management 27 (1): 6-22.

Kellermanns, F. W., and Eddleston, K. A. 2006. "Corporate venturing in family firms: Does the family matter?" Entrepreneurship Theory and Practice 30 (6): 837-854.

Kellermanns, F. W., Eddleston, K. A., Barnett T., and Pearson, A. 2008. “An exploratory study of family member characteristics and involvement: Effects on entrepreneurial behavior in the family firm." Family Business Review 21 (1): 1-14.

Konig, A., Kammerlander, N., and Enders, A. 2013. "The family innovator's dilemma: How family influence affects the adoption of discontinuous technologies by incumbent firms." Academy of Management Review 38 (3): 418-441.

Kotlar, J., and De Massis, A. 2013. "Goal setting in family firms: Goal diversity, social interactions, and collective commitment to family-centered goals." Entrepreneurship Theory and Practice 37 (6): 1263-1288.

Kotlar, J., De Massis, A., Frattini, F., Bianchi M., and Fang, H. 2013. "Technology acquisition in family and nonfamily firms: A longitudinal analysis of Spanish manufacturing firms." Journal of Product Innovation Management 30 (6): 1073-1088.

Lambrechts, F., Voordeckers, W., Roijakkers, N., and Vanhaverbeke, W. 2017. "Exploring open innovation in entrepreneurial private family firms in low- and medium-technology industries." Organizational Dynamics 46 (4): 244-261.

La Porta, R. Lopez-de-Silanes, F., Shleifer, A., and Vishny, R. 1999. "Corporate ownership around the world." Journal of Finance 54 (2): 471-517.

Le Breton-Miller, I., and Miller D. 2008. "To grow or to harvest? Governance, strategy and performance in family and lone founder firms." Journal of Strategy and Management 1 (1): 41-56.

Lloyd, P., and Snelders, D. 2003. "What was Philippe Starck thinking of?" Design Studies 24 (3): $237-253$.

Lumpkin, G.T., and Brigham, K.H. 2011. "Long-term orientation and intertemporal choice in family firms." Entrepreneurship Theory and Practice 35 (6): 1149-1169.

Martin, R. L. 2009. The Design of Business: Why Design Thinking is the Next Competitive Advantage. Boston: Harvard Business Press.

McCormack, J. P., and Cagan, J. 2004. "Speaking the Buick language: Capturing, understanding, and exploring brand identity with shape grammars." Design Studies 25 (1): $1-29$.

McEvily, B., and Zaheer, A. 1999. "Bridging ties: A source of firm heterogeneity in competitive capabilities.” Strategic Management Journal 20 (12): 1133-1156. 
Micheli, P., and Gemser, G. 2016. "Signaling strategies for innovative design: A study on design tradition and expert attention." Journal of Product Innovation Management 33 (5): 613-627.

Miles, M. B., and Huberman, A. M. 1984. Qualitative Data Analysis: A Sourcebook of New Methods. Sage.

Miller, D., Le Breton-Miller, I., Lester, R. H., and Cannella, A. A. 2007. "Are family firms really superior performers?" Journal of Corporate Finance 13 (5): 829-858.

Naldi, L., Nordqvist, M., Sjöberg, K., and Wiklund, J. 2007. "Entrepreneurial orientation, risk taking, and performance in family firms." Family Business Review 20 (1): 33-47.

Perks, H., Cooper, R., and Jones, C. 2005. "Characterizing the role of design in new product development: An empirically derived taxonomy." Journal of Product Innovation Management 22 (2): 111-127.

Ravasi, D., Rindova, V. P., and Stigliani, I. 2018. "History, material memory and the temporality of identity construction." Academy of Management Journal, in press, https://doi.org/10.5465/amj.2016.0505.

Ravasi, D., and Stigliani, I. 2012. "Product design: A review and research agenda for management studies." International Journal of Management Reviews 14 (4): 464-488.

Röd, I. 2016. "Disentangling the family firm's innovation process: A systematic review." Journal of Family Business Strategy 7: 185-201.

Rodan, S., and Galunic, C. 2004. "More than network structure: how knowledge heterogeneity influences managerial performances and innovativeness." Strategic Management Journal 25 (6): 541-562.

Rondi, E., De Massis, A., and Kotlar, J. 2018. "Unlocking innovation potential: A typology of family business innovation postures and the critical role of the family system." Journal of Family Business Strategy, in press, https://doi.org/10.1016/j.jfbs.2017.12.001.

Romano, C. A., Tanewski, G. A., and Smyrnios, K. X. 2001. "Capital structure decision making: A model for family business." Journal of Business Venturing 16 (3): 285-310.

Sanders, E. B. N., and Stappers, P. J. 2008. "Co-creation and the new landscapes of design." CoDesign 4 (1): 5-18.

Schmitt, B., and Simonson, A. 1997. Marketing Aesthetics: The Strategic Management of Brands, Identity and Image. New York: Free Press.

Sciascia, S., and Mazzola, P. 2008. "Family involvement in ownership and management: exploring nonlinear effects on performance." Family Business Review 21 (4): 331-345.

Sharma, P., and Nordqvist, M. 2008. "A classification scheme for family firms: From family values to effective governance to firm performance." In J. Tapies and J. L. Ward (eds.) Family Values and Value Creation: How Do Family-Owned Businesses Foster Enduring Values, New York: Palgrave Macmillan, pp. 71-101.

Sharma, P., Salvato, C., and Reay, T. 2014. "Temporal dimensions of family enterprise research." Family Business Review 27 (1): 10-19.

Siggelkow, N. 2007. "Persuasion with case studies." Academy of Management Journal 50 (1): 20-24.

Sonfield, M. C., and Lussier, R. N. 2004. "First-, second-, and third-generation family firms: a comparison.” Family Business Review 17 (3): 189-202.

Stompff, G. 2003. "The forgotten bond: Brand identity and product design." Design Management Journal 14 (1): 26-32. 
Swan, K. S., and Luchs, M. 2011. "Product design research and practice: Past, present and future." Journal of Product Innovation Management 28 (3): 321-326.

Tushman, M. L., and O'Reilly, C. A. 1996. "Ambidextrous organizations: Managing evolutionary and revolutionary change." California Management Review 38: 8-30.

Verganti, R. 2003. "Design as brokering of languages: The role of designers in the innovation strategy of Italian firms." Design Management Journal (3): 34-42.

Verganti, R. 2006. "Innovating through design." Harvard Business Review 84 (12): 114

Verganti, R. 2009. Design-Driven Innovation. Changing the Rules of Competition by Radically Innovating What Things Mean. Boston: Harvard Business Press.

Villalonga, B., and Amit, R. 2009. "How are US family firms controlled." Review of Financial Studies 22 (8): 3047-3091.

Von Krogh, G., Spaeth, S., and Lakhani, K. R. 2003. "Community, joining, and specialization in open source software innovation: A case study." Research Policy 32 (7): 1217-1241.

Yin, R. K. 2011. Applications of Case Study Research. Thousand Oaks, CA: Sage.

Zahra, S. A. 2003. "International expansion of US manufacturing family businesses: The effect of ownership and involvement." Journal of Business Venturing 18 (4): 495-512.

\section{Appendix A - Operationalisation of Design Renewal and Design Identity}

Design renewal captures the family firm's attitude to exploring collaborations with new designers.

$$
\operatorname{Design} \text { Renewal }(t)=\frac{\sum_{i=1}^{N(t)} \text { Number of New collaborations with designers }(t)_{i}}{N(t)}
$$

Notes: year t; designer(s) $\mathrm{i} ; \mathrm{N}(\mathrm{t})=$ total number of designers collaborating with the company in year $\mathrm{t}$.

Design identity measures the number of years (as a percentage of the number of years the firm has been active in the market) in which the same designer(s) developed at least one product collaborating with the firm.

$$
\operatorname{Design} \operatorname{Identity}(\mathrm{t})=\frac{\sum_{\mathrm{i}=1}^{\mathrm{N}(\mathrm{t})} \text { Memories of Collaboration }(\mathrm{t})_{\mathrm{i}}}{\mathrm{N}(\mathrm{t})}
$$


Numbers of years before $t$ in which the company

Memories of Collaboration $(t)_{i}=\frac{\text { has collaborated with the Designer }(s) i}{(t-\text { Foundation year })}$

Notes: year $\mathrm{t}$; designer(s) $\mathrm{i} ; \mathrm{N}(\mathrm{t})=$ number of designers collaborating with the company in year $\mathrm{t}$ and that have already collaborated with the firm before year $\mathrm{t}$.

\section{Appendix B - Abbreviated interview protocol}

General information on the company: Historical evolution

The firm's history, evolution of the reference market, company acquisitions with external funds, reason for those acquisitions, identification of different phases in the company's history, changes in the organisational chart. Description of the roles within $R \& D$, modification of the R\&D composition over time, positioning of $R \& D$ in the organisational chart.

\section{Family involvement in the firm}

Ownership changes, longitudinal description of the generation involved in the company, focus on intra-family succession, family members involved in management over the firm's history, effects of acquisitions on the family's involvement in the decision-making process.

Collaboration with external designers 
Collaborations with new and historical designers, management of the designers' portfolio, strategic decision about the designers' portfolio, evolution of designers' collaborations.

New product development

Insights on the development of key products over the firm's history, strategic decision taken on new product development, information on the portfolio management of new products.

\section{Appendix C - Organisational Chart}

(Figure 8 about here)

(Figure 9 about here) 


\section{Figures}

\begin{tabular}{|c|c|}
\hline Type of Family Involvement & $\begin{array}{c}\text { Collaborative Innovation in } \\
\text { Design-intensive Firms }\end{array}$ \\
Generation & Design renewal \\
Management & Design identity \\
\hline
\end{tabular}

Figure 1. Theoretical Framework 

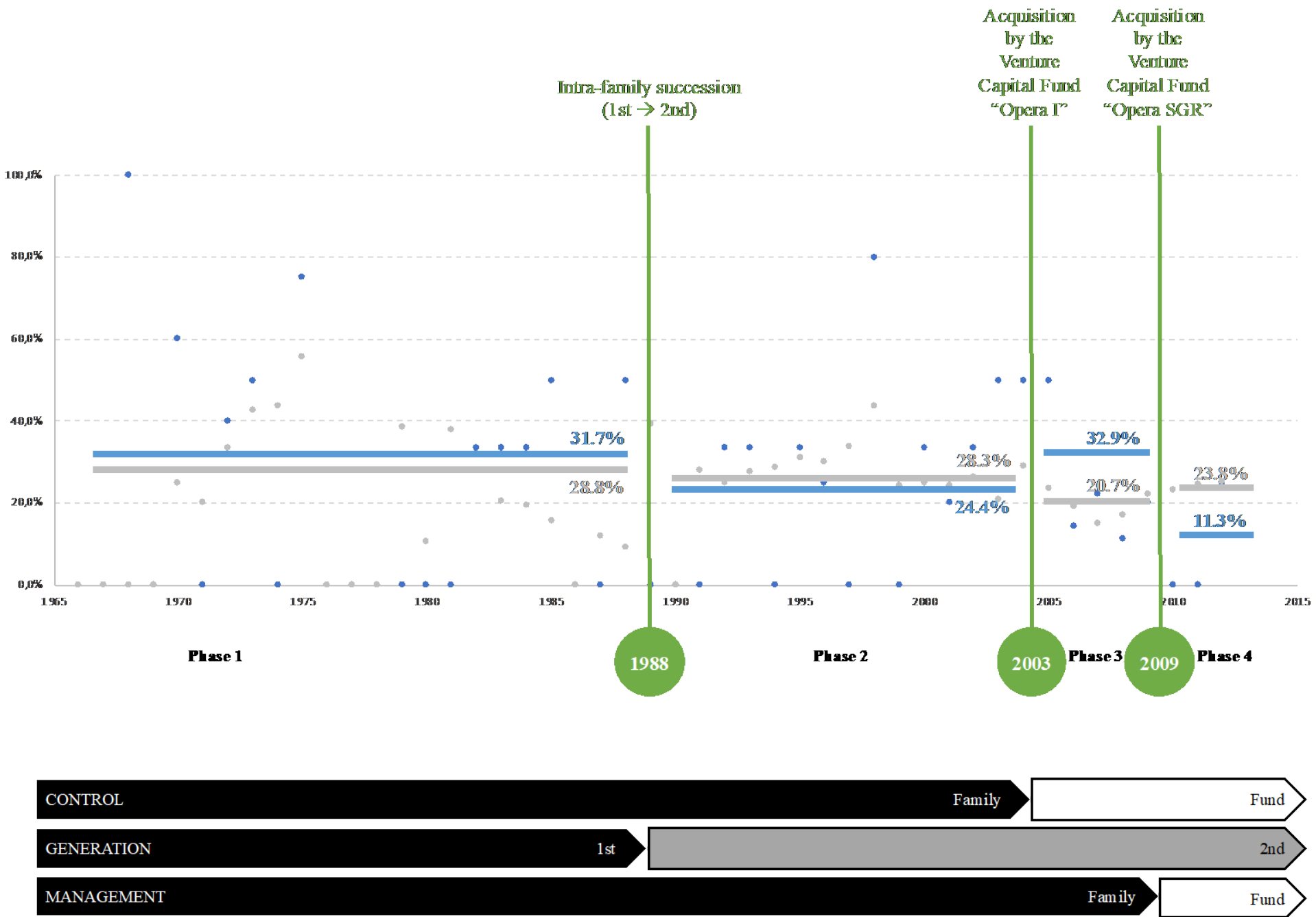

'... R\&D is the heart of our company. This is the reason why the Busnelli family kept it under its own control..."

(Federico Busnelli, R\&D Director)

'... when the fund entered in 2003, we started collaborating with new designers, such as Fukasawa and Urquiola. This decision renewed our designer portfolio ..."

(Maurizio Mozzucchelli, General Manager)

Figure 2. The evolution of Design Renewal and Design Identity in relation to changes in type of family involvement in B\&B Italia. 


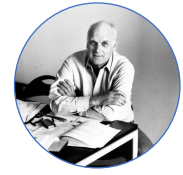

Richard Sapper

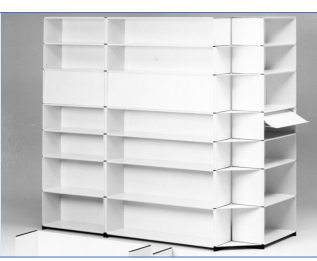

Genia

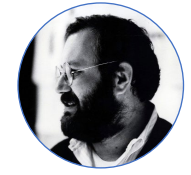

Gianfranco Ferrè

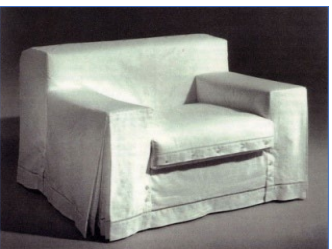

Gli Abiti

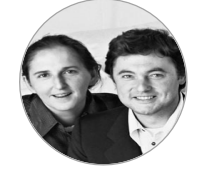

Afra and Tobia Scarpa

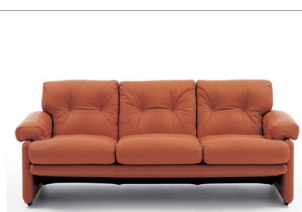

Coronado

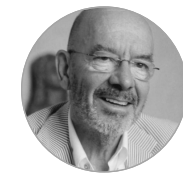

Mario Bellini

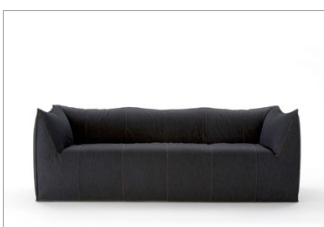

Le Bambole

Figure 3. Examples of new products created by B\&B Italia in Phase 1 (1966-1987)

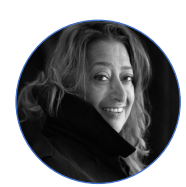

Zaha Hadid

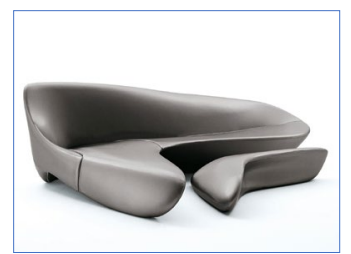

Moon System 2007

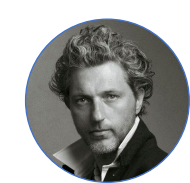

Marcel Wanders

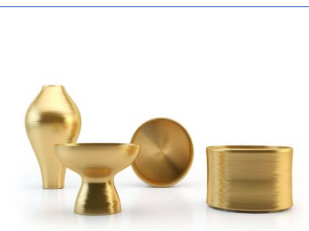

Gold Collection 2007

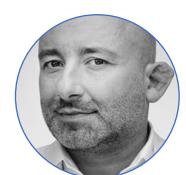

Jean-Marie Massaud

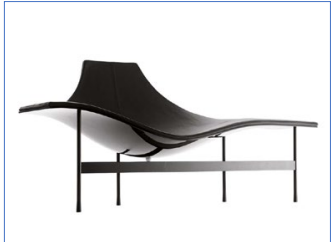

Terminal

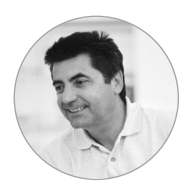

Antonio Citterio

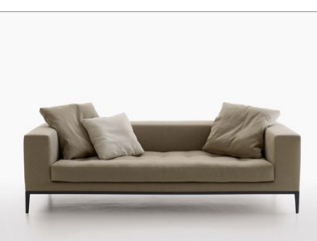

Simplex

Figure 4. Examples of new products created by B\&B Italia in Phase 3 (2003-2008) 

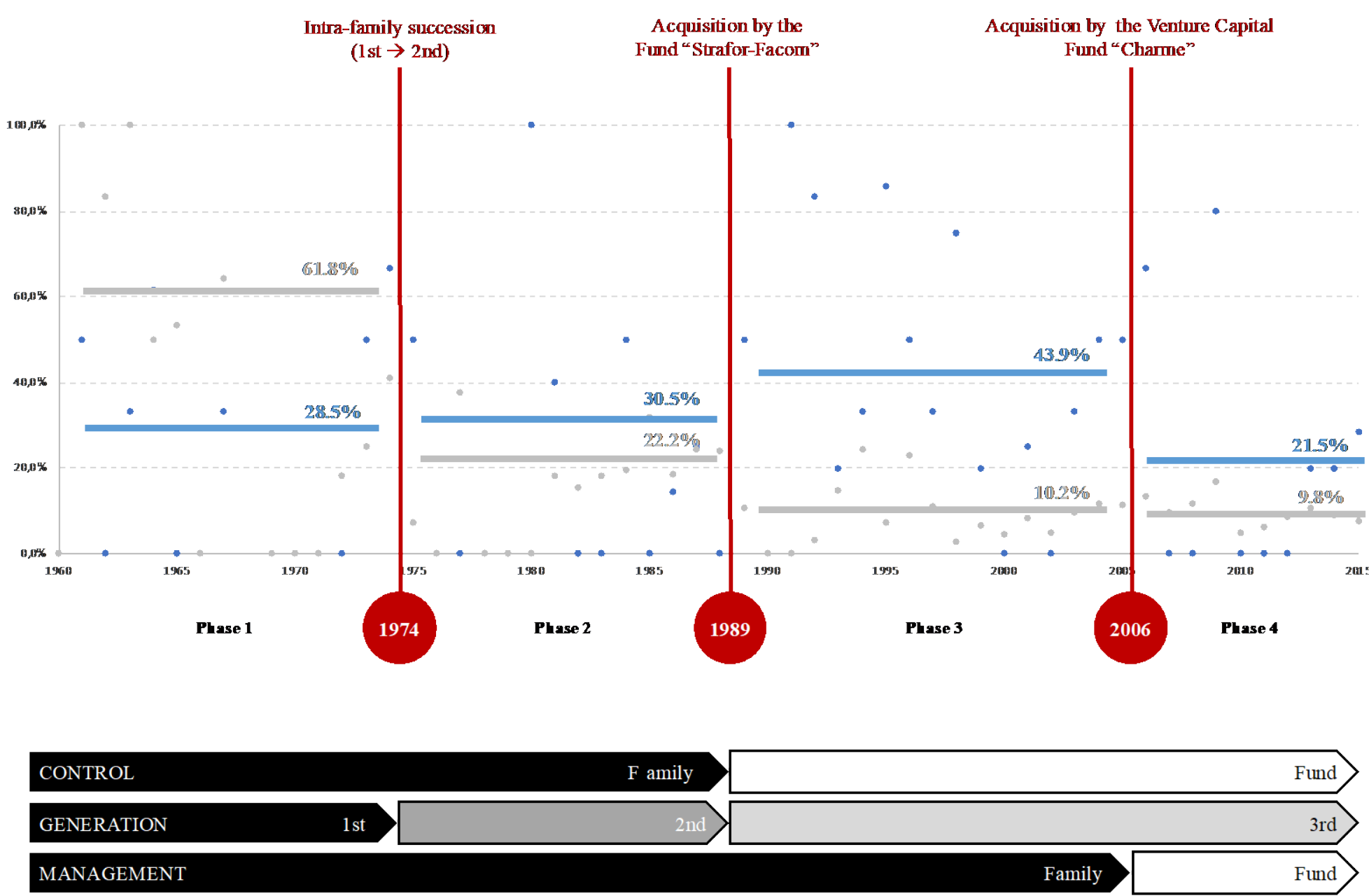

'... when I was involved in the company, I was aware that the second generation helps companies grow, but the third will destroy it. So together with Franco

Cassina, we decided to look for an external investor and we found Strafor-Facom ...' (Rodrigo Rodriquez, General Manager)

'... considering that we are Cassina and have a historical heritage in the field, I was determined in 2007 to share this with society as a whole so we published a book reporting our identity ...'

(Demetrio Apolloni, Brand Director)

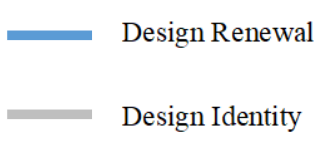

Figure 5. The evolution of Design Renewal and Design Identity in relation to changes in the type of family involvement in Cassina. 


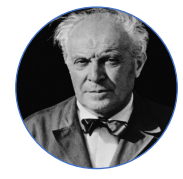

Gio Ponti

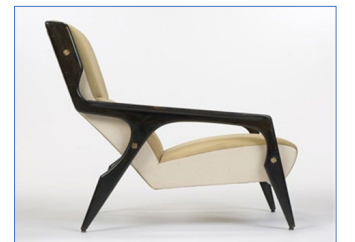

Armchair Hotel Parco dei Principi 1964

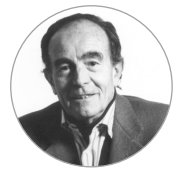

Vico Magistretti

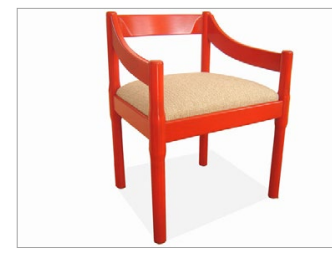

Carimate

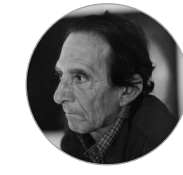

Ico Parisi

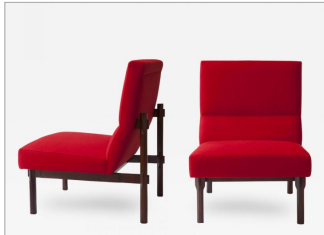

Chairs 86

1961

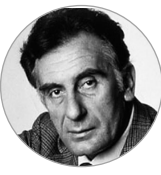

Gianfranco Frattini

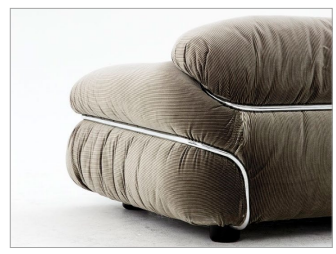

Sesann

Figure 6. Examples of new products created by Cassina in Phase 1 (1960-1973)

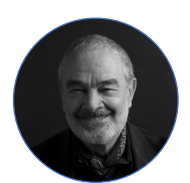

Francesco Binfarè

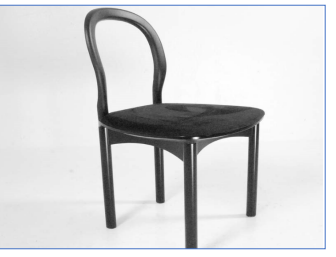

Damia

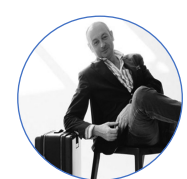

Piero Lissoni

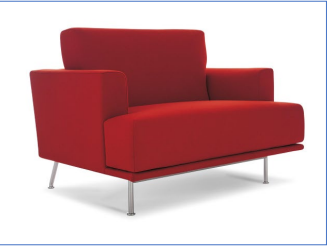

Nest

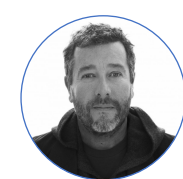

Philippe Starck

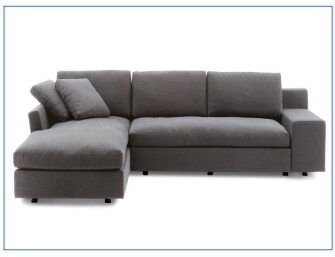

Mister

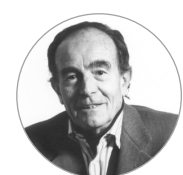

Vico Magistretti

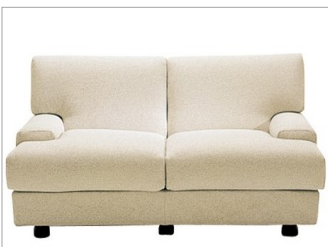

Donegal

Figure 7. Examples of new products created by Cassina in Phase 3 (1989-2005) 
Phase 1

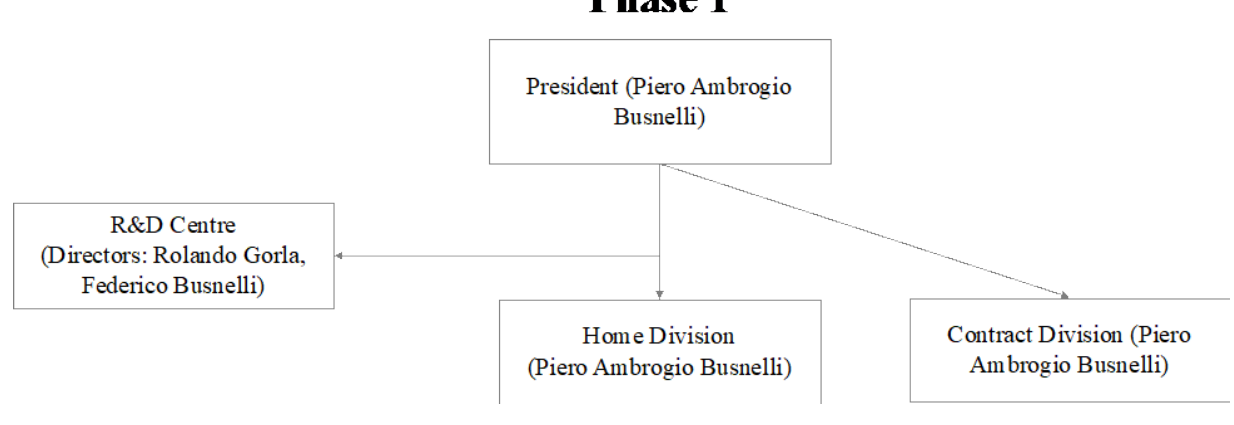

\section{Phase 3}

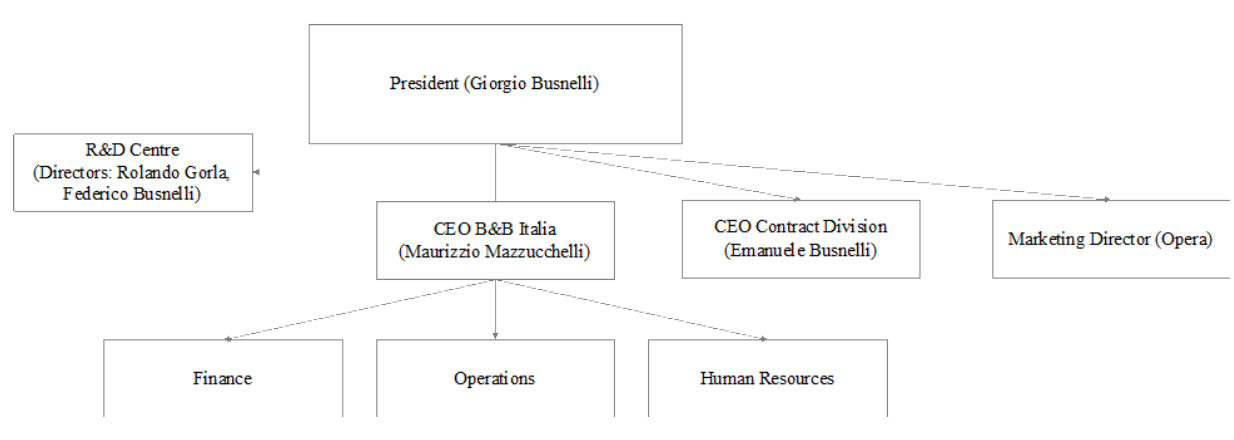

Phase 2
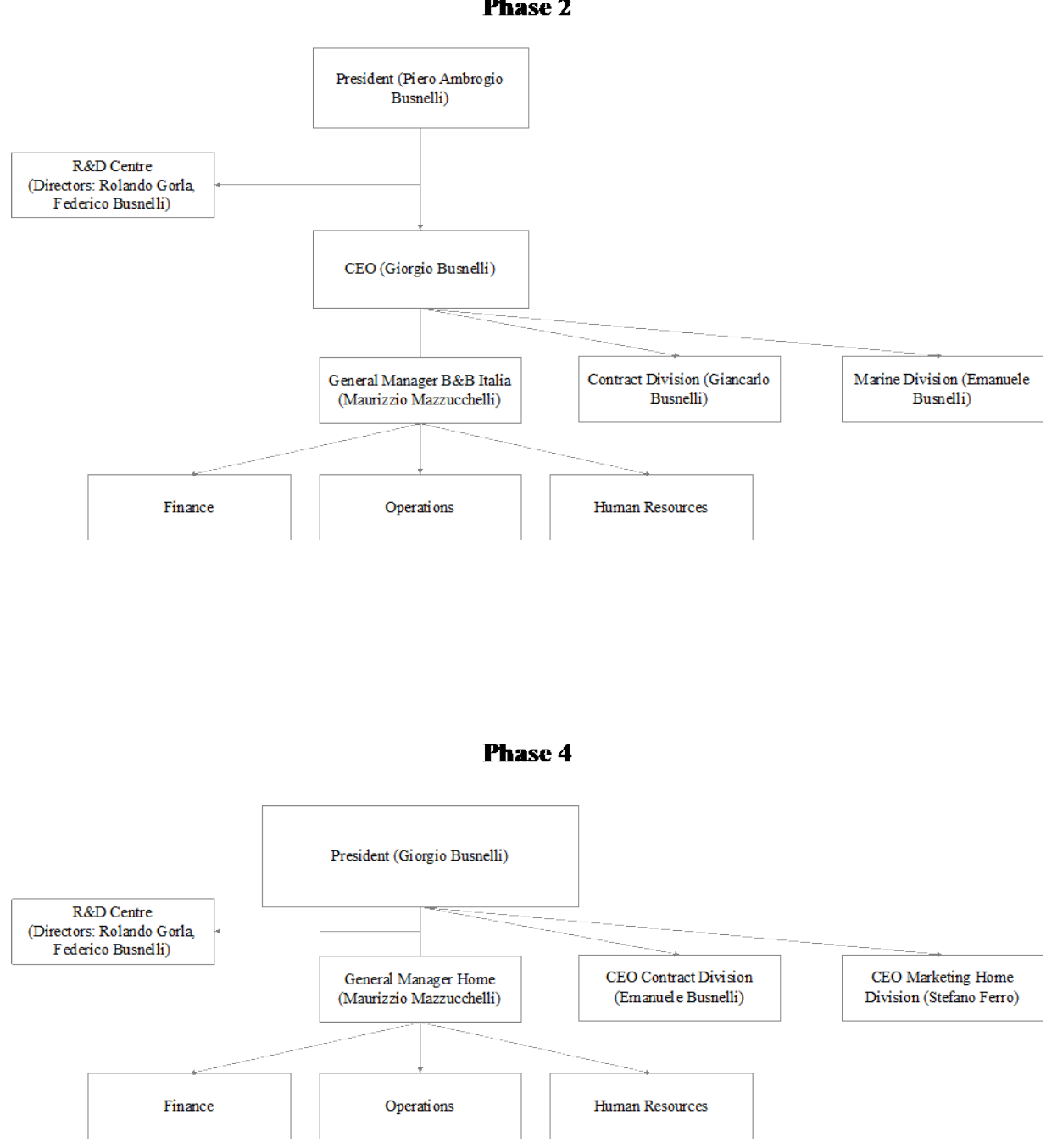

Figure 8. B\&B Italia Organizational Charts Evolutions 

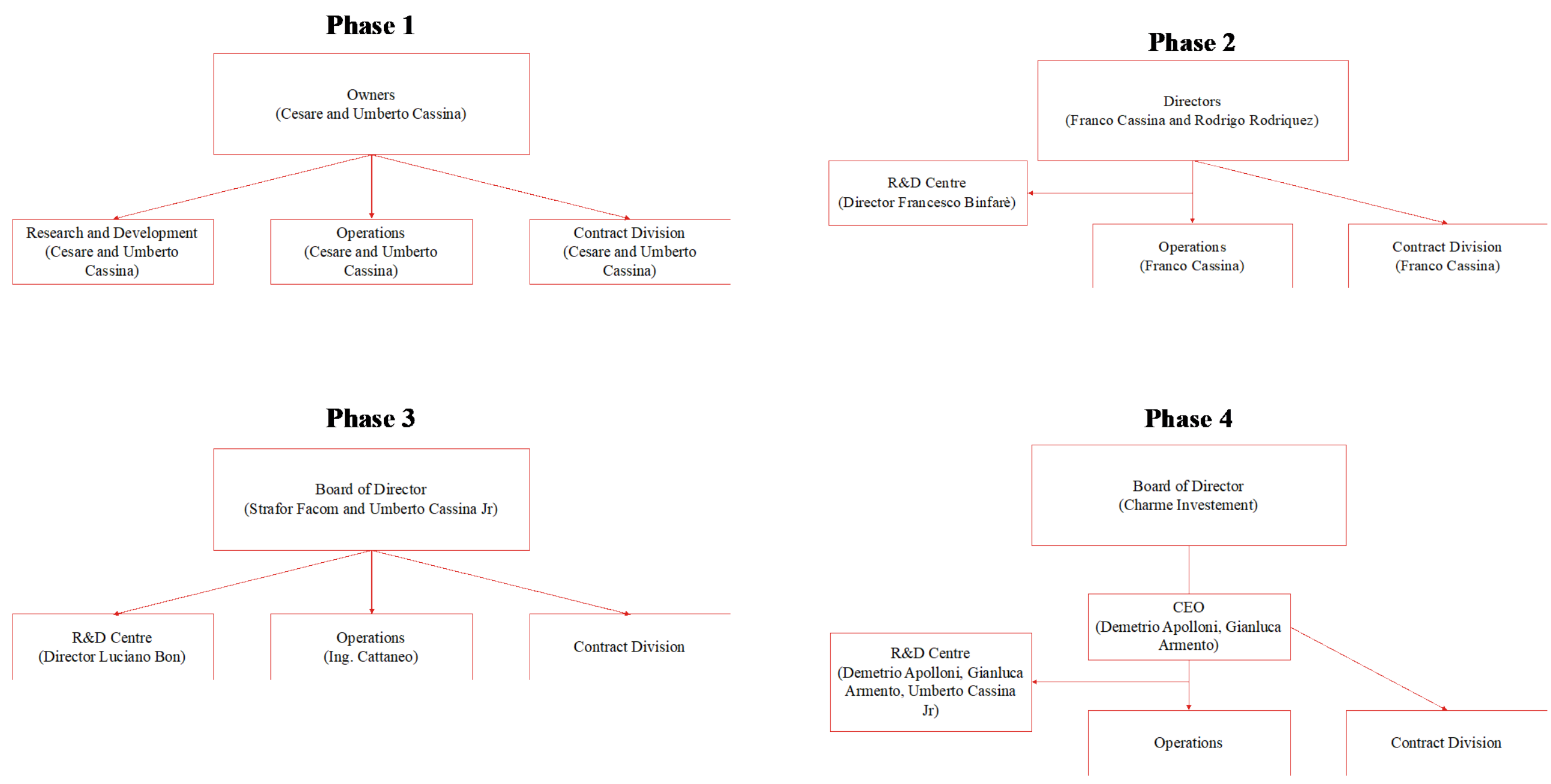

Figure 9. Cassina Organizational Charts Evolutions 